\title{
GIS-BASED EDUCATION COURSE FOR BACHELOR OF MANAGEMENT PROGRAM IN THE LOMONOSOV MOSCOW STATE UNIVERSITY BUSINESS SCHOOL
}

\author{
A. Pirogov
}

JCSC Racurs, 129366, Moscow, Russia - an.pirogov@gmail.com

\author{
Commission VI
}

KEY WORDS: GIS, management, business, education, geography

\begin{abstract}
:
An optional course, "Geographical Aspects of Business" in the framework of the Bachelor of management program in the Lomonosov Moscow State University Business School is setting the goal to introduce future discipline specialists with geographical topics of current interest for management and provide knowledge, skills and expertise of geospatial analysis and the use of geoinformation technologies in finding solutions to economic and managerial tasks. The students' feedback shows interest and demand for such a course for management students. The course has an interdisciplinary links with the main subjects such as marketing, public administration, visual communication, etc., and is based on the set of business cases dealing with Web-GIS Services, LBS, Geomarketing, Spatial analysis, etc. Open Data and corporate geodata sets are used. The pragmatist approach is selected for successful accomplishment of the course's goal, which is based on using Web-GIS tools. The Geomixer - a free webGIS product by the company SCANEX - is chosen to be one of them. The principle "I do - I analyze" helps to minimize the theoretic constituent of the course improving the outcome of the classes. Owing to innovative methods of teaching, the educational goal of the course is achieved to the full scope despite the small number of allocated hours. The classes surely improve both the general level of geographic competence of students and provide them with the skills to work with GIS. Such optional courses will undoubtedly contribute to the development of GIS-education in management administration.
\end{abstract}

\section{GIS EDUCATION}

\subsection{Background}

The book "Thinking about GIS" by Tomlinson Roger contains correct words that passed time verification and were confirmed by many business-practices: "No GIS can be a success without the right people involved. A real-World GIS is actually a complex system of interrelated parts, and at the center of this system is a smart person who understands the whole". Geographic Information System in curriculum plays an important role in the new generation of educational standards for higher educational establishments accepted in Russia since 2010. Studying GIS is planned for the following profile concentrations: Geodesy and Remote Sensing, Cartography and Geoinformatic. The discipline "GIS in geography" is introduced for the concentration "Geographer". Ecologists-natural resource users and soil scientists study a similar subject. Necessary skills, knowledge and competence need while working with Geographic Information System are included into standards for silviculture specialists, hydrometeorologists, town-planners. The important fact is that the interdisciplinary links between GIS, mathematic, informatic, and natural training division have been determined. Unfortunately, area studies specialists, urban planners, geologists, agricultural specialists for whom GIS is a key informational tool, do not study GIS. Particularity of education often divides the GIS specialists for "engineering experts" who can program well and "geographers" ("humanitarians") who understand the regularities and processes of geographical and socioeconomic space.

Growing volumes of geospatial data, development of information technologies and improvement of geodata analysis methods lead to the fact that obtaining the Geographic Information Systems and capability to analyse geodata exceed the bounds of the core competence. Several years ago the author conducted a questioning of several scores of middle managers who are not professionally linked with GIS and geography. The following results were obtained. See table 1 .

\begin{tabular}{|c|c|c|}
\hline Questions & Yes & No \\
\hline $\begin{array}{l}\text { 1) Does your company use geospatial } \\
\text { (geographical) analyses of any data? }\end{array}$ & $45 \%$ & $55 \%$ \\
\hline $\begin{array}{l}\text { 2) Is there a professional geoinformation } \\
\text { system among information technologies used } \\
\text { by your company? }\end{array}$ & $36 \%$ & $64 \%$ \\
\hline $\begin{array}{l}\text { 3) Do you think that knowledge of geography } \\
\text { obtained at school or in the university is } \\
\text { enough for today }\end{array}$ & $40 \%$ & $60 \%$ \\
\hline $\begin{array}{l}\text { 4) Do you agree that a good level of } \\
\text { geographical knowledge is an integral } \\
\text { part of professional competence of a } \\
\text { manager? }\end{array}$ & $67 \%$ & $33 \%$ \\
\hline
\end{tabular}

Table 1. Middle managers research results.

Obtained data shows that geographical knowledge and skills of GIS are in great demand between high-skilled managers.

The degree of utilizing geoinformation technology in various fields of business depends on the number of specialists who understand the efficiency of those technologies and possess a certain set of skills for working with them. As for the most popular professions, such as business administration, finance and economy, marketing, and analytic professionals, who often become GIS/GEOdata customers, there are no geo-technology classes provided in the basic educational programs. Conferences, training courses, seminars, and master classes on various GIS and GEO aspects are held in many countries on a 
regular basis, but the author suggests they will not have a dramatic influence on general GIS-education and on development rates of geoinformation technologies.

\subsection{Lomonosov Moscow State University Business School}

Established in 1755 Lomonosov Moscow State University (MSU) is the oldest and the most famous university in Russia. Today Moscow State University offers training in almost all branches of modern science and humanities. More than 40,000 graduate and post-graduate students, and about 7,000 undergraduates study at the university, and over 5,000 specialists take MSU refresher courses each year. Moscow State University comprises 40 faculties and schools, 15 research institutes, 23 scientific and applied centres. Lomonosov Moscow State University Business School (Lomonosov MSU BS) founded in 1989 in Moscow State University is one GSBA Business School Moscowof the oldest business schools in Russia. Lomonosov MSU BS's programmes (Bachelor of Management, Master in International Business, MBA, Executive MBA Programmes and Doctoral Programme (PhD) are designed to meet the most sophisticated needs of modern Russian and foreign students. Lomonosov MSU BS successfully integrates the traditional approach with new approaches that view teaching management as a contemporary art of doing business.

Having strong connections with Russian business world, Lomonosov MSU BS also offers tailor-made corporate programmes. Lomonosov MSU BS was ranked \#1 in Russia according to the surveys held by the leading business magazine Secret Firmy in 2007, 2008 and 2010. In 2011 Lomonosov MSU BS was named one of the "Best business school at Eastern Europe" by Eduniversal ranking. Lomonosov MSU BS offers the four basic educational programs: "Bachelor of Management," "Master in International Management," "MBA," and "Executive MBA" that ensure quality training in the best traditions of the university. Close cooperation with leading companies provides students with a unique opportunity to get involved in solving practical business tasks early in the process of training. All Lomonosov MSU BS degree-granting programmes build on the use of action-oriented methods of teaching: practical exercises, case method, business games, and group projects, supported by business information system. These methods encourage students to internalize and activate the disciplines studied and simultaneously develop teamwork skills.

\section{GIS BASED EDUCATION COURSE}

\subsection{Interdisciplinary background}

The author introduced an optional course "Geographical Aspects of Business" for bachelors of management program in Lomonosov Moscow State University Business School in 2011. The course is offered in the first semester of the fourth year and takes 32 hours. Every year about 20 students choose this course. An optional course is setting the goal to introduce future discipline specialists with geographical topics of current interest for management and provide knowledge, skills and expertise of geospatial analysis and the use of geoinformation technologies in finding solutions to economic and managerial tasks. The students' feedback showed interest and demand for such a course for management students. Initial testing of students as a rule demonstrates different levels of basic geographical knowledge, almost total absence of ideas about GIS, and poor understanding of business administration structure in the geospatial industry.

Studying of geographical aspects of management allows the students to learn geospatial analyses methods, forms the skills of using geographical information and geoinformation systems as an effective tool for decision-making. General knowledge of geography forms geographical thinking necessary for personal and professional growth of a manager.

Growth of business demand in GIS solutions leads to an increase in interdisciplinary links situated on the edge of geography and management. The author uses such links as a course basis during development of educational modules. Table 2 contains some disciplines from Bachelor of Management program. $1 / 4$ out of 59 disciplines that belong to professional, economic, academic, mathematic and natural educational-cycle have close links with geography and GIS. See table 2.

\begin{tabular}{|c|c|c|}
\hline $\begin{array}{l}\text { MSU BS bachelor } \\
\text { programme courses }\end{array}$ & $\begin{array}{l}\text { Interdisciplinary } \\
\text { topics }\end{array}$ & $\begin{array}{l}\text { GIS/GEO } \\
\text { course } \\
\text { modules }\end{array}$ \\
\hline $\begin{array}{l}\text { Fundamentals of } \\
\text { Demography, } \\
\text { Economic and social } \\
\text { world geography, } \\
\text { Regional Economics, } \\
\text { Economic and } \\
\text { Geographic, } \\
\text { Fundamentals of } \\
\text { Business, } \\
\text { Concepts of } \\
\text { Contemporary, } \\
\text { Natural Sciences. }\end{array}$ & $\begin{array}{l}\text { Physic- } \\
\text { Geographical } \\
\text { Conditions }\end{array}$ & $\begin{array}{l}\text { Economical-- } \\
\text { Geographical } \\
\text { Position, } \\
\text { Web-Mapping. }\end{array}$ \\
\hline $\begin{array}{l}\text { Accounting, } \\
\text { State and Municipal } \\
\text { Management, } \\
\text { Global Limits to } \\
\text { Economic Growth, } \\
\text { Relations Between } \\
\text { Public Service and } \\
\text { Business. }\end{array}$ & $\begin{array}{l}\text { Management of } \\
\text { Territory }\end{array}$ & $\begin{array}{l}\text { Cadastre, } \\
\text { Territory } \\
\text { Development, } \\
\text { Territory } \\
\text { Branding and } \\
\text { Marketing. }\end{array}$ \\
\hline $\begin{array}{l}\text { Methodology of } \\
\text { Empirical Research, } \\
\text { Insurance and Risks, } \\
\text { Managerial Skills } \\
\text { and Decision } \\
\text { Making, } \\
\text { Financial } \\
\text { Accounting, } \\
\text { Analysis and Audit, } \\
\text { Statistics. } \\
\end{array}$ & $\begin{array}{l}\text { Geospatial } \\
\text { Analysis }\end{array}$ & $\begin{array}{l}\text { Geospatial } \\
\text { Data Mining, } \\
\\
\text { Infrastructure } \\
\text { of Spatial } \\
\text { Data. }\end{array}$ \\
\hline $\begin{array}{l}\text { Visual } \\
\text { Communications, } \\
\text { Information } \\
\text { Technologies in } \\
\text { Business, } \\
\text { Computer Science. }\end{array}$ & $\begin{array}{l}\text { Geographical } \\
\text { Information } \\
\text { System }\end{array}$ & $\begin{array}{l}\text { GIS, } \\
\text { Web- } \\
\text { Mapping, } \\
\text { Web-GIS, } \\
\text { Geoportal. }\end{array}$ \\
\hline $\begin{array}{l}\text { Marketing } \\
\text { Communications, } \\
\text { Marketing, } \\
\text { Innovation } \\
\text { Management, } \\
\text { Social Psychology. }\end{array}$ & Geomarketing & $\begin{array}{l}\text { Geomarketing, } \\
\text { Territory } \\
\text { Branding and } \\
\text { Marketing, } \\
\text { Location Base } \\
\text { Service. }\end{array}$ \\
\hline
\end{tabular}

Table 2. Interdisciplinary background 


\subsection{GIS software and Geospatial data}

Unlike the CRM-systems (Customer Relationship Management systems), which have long become part of the studied IT-tools, GIS do not get adequate consideration in "Economics and Administration" training. However, global practice demonstrates that managers, market researchers, financial analysts, and insurance and logistics specialists have been increasingly relying on geoinformation systems for the arrangement, analysis, and representation of business data regardless of the patterns of ownership and levels of companies' capitalization. The ability to work with geospatial information is an important constituent of management. Many business processes are closely connected with geographic aspects and could be realized using GIS tools and imagery data mining methods.

The most prevalent model for GIS use in classroom is using GIS software on personal computers. The pragmatist approach was selected for successful accomplishment of the course's goal, which is based on using Web-GIS. The Geomixer - a free web-GIS product by the company SCANEX (Russia) was chosen to be one of them. The system complies with the requirements for used Web-GIS in education:

- Web browser engine: API, on-line and off-line access, ease of use configuration, intuitive interface;

- Multi-user capabilities: unmetered simultaneous connections, individual login/password, database connection, user administration, network data exchange, networking on maps and layers;

- Data exchange and processing: export and import of the most common geoformat (GeoTIFF, .shp, .kml/kmz), attributive and table data processing, WMS-support, direct url-links on a created map;

- Data creation and analysis: vectorization tools, buffering, attributing, searching, ranging, etc.

- Base map: World Base Map, OpeenStreetMap, high resolution imagery, SRTM.

Technical support and a free license for education purposes also play significant role.

Geographic fundamentals are laid by the analytical work with geospatial information. Map - is a language of geography and an interactive business instrument. Geospatial data in business may be shown in different formats. The most popular format is a table. Students work with such data during analyses of business processes. The partner-companies of the faculty provide the students with real business data that are used in the frames of the course. These data include operating business-statistics of different business-entities: branches, shops, filling stations and so on. Besides the provided data there are used data bases of State Statistics Service of Russia, official customs, economic and demographic reports, open data of Moscow city Government. Often such data contain geographic (continent, country, city) or address fixup (city, index, street, house) that allowed to geocode them easily and visualize them on a map. Geocontent of Geomixer is represented below and publicly available by the link: http://geo.mgubs.ru:8080/api/index.html

\begin{tabular}{|l|l|l|}
\hline Map & Layers & Functionality \\
\hline Training map & World DEM & Demonstrates \\
& Climatic zones & different \\
& International group & Economical - \\
& of countries & Geographical \\
& Capitals & conditions. \\
& Geospatial tasks & $\begin{array}{l}\text { Set of training } \\
\text { materials. }\end{array}$ \\
& & Handling of \\
\hline Social & Local DTM/DEM & \\
\hline
\end{tabular}

\begin{tabular}{|l|l|l|}
\hline $\begin{array}{l}\text { infrastructure of } \\
\text { Moscow }\end{array}$ & $\begin{array}{l}\text { Districts } \\
\text { Wards with } \\
\text { population } \\
\text { Functional zones } \\
\text { Underground with } \\
\text { walking distance } \\
\text { Filling stations } \\
\text { Several points layer }\end{array}$ & $\begin{array}{l}\text { applied problems } \\
\text { and skill training. }\end{array}$ \\
\hline $\begin{array}{l}\text { Business } \\
\text { research map } \\
\text { (limited access) }\end{array}$ & $\begin{array}{l}\text { Corporate points } \\
\text { and polygons layers }\end{array}$ & $\begin{array}{l}\text { Brainstorms. } \\
\text { Practice. Decision } \\
\text { making. }\end{array}$ \\
\hline $\begin{array}{l}\text { Student maps } \\
\text { (limited access) }\end{array}$ & Individual maps & $\begin{array}{l}\text { Individual } \\
\text { training and } \\
\text { homework }\end{array}$ \\
\hline Users maps & $\begin{array}{l}\text { Geomixer is } \\
\text { publicly available } \\
\text { for users' data } \\
\text { processing. }\end{array}$ & $\begin{array}{l}\text { Can be used by } \\
\text { lecturers, students } \\
\text { of MSU BS and } \\
\text { all stakeholders. }\end{array}$ \\
\hline
\end{tabular}

Table 3. Geocontent of Geomixer

\subsection{Course structure and educational form}

The principle "I do - I analyze" helped to minimize the theoretic constituent of the course improving the outcome of the classes. Lessons are based on simulation of a business-process with using GIS tools and geospatial analysis methods. Each

\begin{tabular}{|c|c|c|}
\hline Course' modules & $\begin{array}{l}\text { Educational } \\
\text { form }\end{array}$ & Results \\
\hline $\begin{array}{l}\text { Physic-Geographical } \\
\text { Position. Geospatial } \\
\text { Data. Geocoding. Web- } \\
\text { GIS review. }\end{array}$ & $\begin{array}{l}\text { Individual and } \\
\text { cooperative } \\
\text { learning }\end{array}$ & $\begin{array}{l}\text { Introduction to } \\
\text { GIS. "Cut teeth". }\end{array}$ \\
\hline $\begin{array}{l}\text { Web-Mapping - Theory } \\
\text { and Practice. GIS/Geo } \\
\text { industry review. }\end{array}$ & $\begin{array}{l}\text { Individual } \\
\text { and } \\
\text { cooperative } \\
\text { learning }\end{array}$ & $\begin{array}{l}\text { Tools and data } \\
\text { skills. Immerse in } \\
\text { study. }\end{array}$ \\
\hline $\begin{array}{l}\text { Geospatial Analysis and } \\
\text { Data Mining. }\end{array}$ & $\begin{array}{l}\text { Cooperative } \\
\text { learning }\end{array}$ & $\begin{array}{l}\text { Mind changing. } \\
\text { Business cases. }\end{array}$ \\
\hline Geomarketing and LBS. & $\begin{array}{l}\text { Individual and } \\
\text { cooperative } \\
\text { learning }\end{array}$ & $\begin{array}{l}\text { Real-life business } \\
\text { cases. Problem } \\
\text { solving. }\end{array}$ \\
\hline $\begin{array}{l}\text { Tour of a geospatial } \\
\text { market company }\end{array}$ & Team teaching & "Outward glance" \\
\hline $\begin{array}{l}\text { Territory Management, } \\
\text { Place Branding and } \\
\text { Marketing. }\end{array}$ & $\begin{array}{l}\text { Individual } \\
\text { and } \\
\text { cooperative } \\
\text { learning } \\
\end{array}$ & $\begin{array}{ll}\text { Real-life } & \text { business } \\
\text { cases. } & \text { Problem } \\
\text { solving. } & \end{array}$ \\
\hline $\begin{array}{l}\text { SDI, NSDI, Corporate } \\
\text { and State Geoportals }\end{array}$ & $\begin{array}{l}\text { Cooperative } \\
\text { learning }\end{array}$ & $\begin{array}{ll}\text { Real-life } & \text { business } \\
\text { cases. } & \text { Problem } \\
\text { solving. } & \\
\end{array}$ \\
\hline \multicolumn{2}{|c|}{$\begin{array}{l}\text { Reinforcement of learning, team project } \\
\text { analysis. }\end{array}$} & Master skills \\
\hline
\end{tabular}

Table 4. Modules and educational forms

business-case consists of a handout (in digital or analog form). This handout is a data set for GIS and also a description of business-task that should be simulated in order to make decision based on geodata analysis. Besides GIS-tools usage, in common practice is usage of paper maps (school atlas, cartographical web services (GoogleEarth, Yandex-maps, etc), interactive statistics appendices (e.g. Gapminder). Much attention is paid to 
formation of space orientation for which mental maps creation method is used. These maps reflect the relative position of world main geographic objects.

Different forms of education allow increasing the course effectiveness as a whole. Individual, cooperative and team learning methods are used.

Individual learning. Personal success is based on motivation. Preliminary testing of students shows personal preferences. These preferences are used for individual task set and usage of strong skills of each student during brainstorms. It's also important to analyze how GIS can improve student' graduation work.

Cooperative learning. Formation of work-groups is helpful because it is possible to smooth the general level of computer competence when working with GIS. As a rule, geographical analysis means the investigation of a set of characteristics, factors and conditions. They have volume too big to be fulfilled by one person that is why during the education process workgroups were formed. These groups consist of 2-3 students. Tasks divide for execute phases. On the first phase the workgroup forms and downloads their set of geodata into GIS, on the second phase a thematic map based on data of all work-groups is formed, on the third phase geographical research of these data is made. Such research can be made individually as well as in a group.

Team project. As mentioned above, MSU BS has stable relations with Russian business world. In the frame of Partner Research Project geospatial analysis of corporate business data is implemented. This allows solidifying knowledge, reinforcing skills and demonstrates high value of geospatial tools and methods in real business.

\subsection{Educational business tour}

To reinforce hands-on constituents of the training and to follow the traditions of the MSU BS the course includes an annual tour of the SCANEX Company. SCANEX Research and Development Center the leading Russian company on the remote sensing market that offers a complete set of services ranging from acquisition to thematic processing of Earth observation images from space. During the tour students get familiar with activities of the company in the area of remote sensing data processing and implementation of integrated GISprojects aimed at solving a variety of tasks.

\section{CONCLUDING REMARKS}

Owing to innovative methods of teaching, the educational goal of the course is achieved to the full scope despite the small number of allocated hours, and the received feedback demonstrates its popularity. The classes surely improve both the general level of geographic competence of students and provide them with the skills to work with GIS. Such optional courses will undoubtedly contribute to the development of GEOeducation and the use of GIS in management administration.

\subsection{Acknowledgements}

I wish to thank the Lomonosov Moscow State University Business School for support of the course and the GIS-Lab.info web community for useful comments.

\section{References from Journals:}

Bednarz, S.W., 2004. Geographic information systems: A tool to support geography and environmental education? GeoJournal, 60, pp. 191-199.

Haubrich H., Reinfried S., Schleicher Y. 2007. Lucerne Declaration on Geographical Education for Sustainable Development. Geographical Views on Education for Sustainable Development. Geographiedidaktische Forschungen, V. 42, p. 243-250.

Pirogov A. 2011. GIS-Education in the MSU Graduate School of Business Administration. Earth from Space. 11, p. 62-65.

\section{References from Books:}

Roger Tomlinson. 2003. Thinking About GIS: Geographic Information System Planning for Managers. Esri Press. P. 280.

\section{References from Other Literature:}

United Nations. 2000. Handbook on geographic information systems and digital mapping. Studies in Methods. Series F No. 79, p. 205.

Palladino S., 1996. Critical Issues in GIS-Based Educational Module Development: NCGIA's ArcView-based Color Your World Module. NCGIA Technical Report Series. Report 96-6. p. $1-20$

Pirogov A., Merkusheva O. 2012. Interactive Geographic Information System for business-education. Proceedings of the $3^{\text {rd }}$ Conference "Interactive Education", Lomonosov MSU, December, 2012, pp. 76-78. 